\title{
Metasieciowe ujęcie organizacji IT z perspektywy najmniej zintegrowanych spotecznie aktorów ${ }^{1}$
}

\author{
Dr hab. Anna Ujwary-Gil, prof. INE PAN iD \\ Instytut Nauk Ekonomicznych Polskiej Akademii Nauk \\ Pracowania Analiz Procesowych i Sieciowych
}

\section{Wprowadzenie}

Metasieciowe ujęcie funkcjonowania organizacji to jedno z ciekawszych ujęć w powiązaniu z kształtującym się w naukach o zarządzaniu paradygmatem sieciowym. Paradygmat ten ${ }^{2}$ wyróżnia stosowane podejście badawcze, w tym: zbieranie i zarządzanie danymi sieciowymi, cechy danych sieciowych, poziom analiz i zmienne sieciowe pozyskane $\mathrm{z}$ danych, które zostaną pokrótce przedstawione $\mathrm{w}$ tym opracowaniu. Podejście sieciowe pozwala spojrzeć na organizację z wielomodalnej perspektywy, obejmującej aktorów ${ }^{3}$ społecznych (pracowników), ich wiedzę i umiejętności, zasoby i zadania. Możemy przyjąć, że organizacja opiera się przynajmniej na tych czterech współzależnych elementach, pozwalających opisać organizację w jej działaniu.

Celem rozdziału jest analiza organizacji sektora informatycznego przez pryzmat aktorów społecznych w sieci organizacyjnej, ich pozycji w sieci, poziomu integracji, powiązań w sieci społecznej, z uwzględnieniem atrybutu sieciowego, jakim dla potrzeb tych badań będzie doświadczenie zawodowe pracowników. Zakres badań obejmuje organizację oferującą zaawansowane rozwiązania informatyczne dla biznesu i nie tylko, o wysokim natężeniu zasobów niematerialnych w jej działaniu,

1 Rozdziat zostat przygotowany w ramach badań statutowych prowadzonych w Instytucie Nauk Ekonomicznych Polskiej Akademii Nauk na rok 2020.

2 Zob. A. Austen, Efektywność sieci publicznych. Podejście wielopoziomowe, Wydawnictwo C.H. Beck, Warszawa 2014; W. Czakon, Paradygmat sieciowy w naukach o zarzqdzaniu, „Przegląd Organizacji” 2011, nr 11, s. 3-6; A. Ujwary-Gil, Audyt zasobów niematerialnych z wykorzystaniem analizy sieci organizacyjnej, Wydawnictwo Naukowe PWN, Warszawa 2017.

3 W badaniach termin aktor (A) używany będzie zamiennie z terminami osoba i pracownik. 
w której wiedza i umiejętności odgrywają kluczową rolę. Zastosowano metodykę badań sieciowych opartą na podstawowym założeniu, jakim jest współzależność analizowanych elementów metasieciowego ujęcia organizacji, co zdecydowanie wyróżnia to podejście od innych stosowanych w badaniach społecznych, gdzie obserwacje są wobec siebie niezależne.

Główną przesłanką podjęcia tych badań jest zrozumienie złożoności funkcjonowania organizacji jako systemu społeczno-technicznego powiązanego zbiorem współzależnych sieci relacji. Metasieć pozwala na symultaniczną analizę wielu połączonych ze sobą elementów w systemie społeczno-technicznym organizacji. Wykorzystując wielomodalną perspektywę sieci oraz mierniki sieciowe, możemy zmierzyć pozycję aktorów społecznych w sieci organizacyjnej i optymalizować planowane działania. Za pomocą tradycyjnych schematów organizacyjnych nie jest możliwe zmierzenie złożonej sieci oddziaływań między aktorami społecznymi organizacji, przepływu informacji, wykorzystywanej wiedzy i umiejętności, zasobów oraz wykonywanych zadań.

Opracowanie podejmuje próbę odpowiedzi na następujące pytania badawcze:

1) „Którzy aktorzy są najmniej zintegrowani zadaniowo w sieci organizacyjnej?”;

2) „Którzy aktorzy są najmniej powiązani społecznie w sieci organizacyjnej?”;

3) „Którzy aktorzy mają najniższą świadomość sytuacji w sieci organizacyjnej?”;

4) „Czy doświadczenie mierzone liczbą lat pracy może mieć wpływ na pozycję aktora w sieci?”.

\section{Kontekst teoretyczny badań}

Kontekstem teoretycznym badań i pytań badawczych są teoria sieci, teoria aktora-sieci, teoria działalności, teoria zasobowa oraz teoria złożoności, które tworzą podwaliny pod interpretację zachowań aktorów społecznych organizacji oraz zrozumienie współzależności występujących w metasieci organizacyjnej.

Według założeń teorii sieci ${ }^{4}$ pozycja aktora w sieci determinuje jego ograniczenia i szanse w kategorii jego osiągnięć, zachowań czy przekonań. Efektywność sieci można ocenić przez pryzmat mogącej wystąpić fragmentacji (niepowiązanych węzłów w sieci) oraz redundancji (nadmiarowości) węzłów i relacji. W powiązaniu z przedstawionymi w sekcji metodycznej miernikami sieciowymi (vide

4 Zob. A.-L. Barabási, Network theory - the emergence of the creative enterprise, "Science” 2005, vol. 308, no. 5722, s. 639-641; S.P. Borgatti, D.S. Halgin, On network theory, „Organization Science" 2011, vol. 22, no. 5, s. 1168-1181; R.S. Burt i wsp., Contingent organization as a network theory: The culture-performance contingency function, „Acta Sociologica” 1994, vol. 37, no. 4, s. 345-370; G.R. Salancik, Wanted: A good network theory of organization, „Administrative Science Quarterly" 1995, vol. 40, no. 2, s. 345-349. 
więzi simmeliańskie) przynależność do nakładających się klik ma również znaczenie teoretyczne. W przypadku gdy dwoje ludzi w organizacji łączy relacja koleżeńska i należą oni do jednej lub kilku klik, ich relacje są osadzone w społecznym kontekście norm i wartości, który ogranicza stopień, w jakim para jednostek może tworzyć własne normy i wartości. Diadyczna więź między dwojgiem ludzi należących do tej samej kliki została nazwana więzią simmeliańskią (Simmelian tie) $)^{5}$. Simmel ${ }^{6}$ omówił, w jaki sposób trzyosobowe kliki (triady) różnią się od relacji dwuosobowych (diad). Triady mają tendencję do tłumienia indywidualnych interesów, zmniejszania indywidualnej władzy i miarkowania konfliktu. Poszczególne interesy w ramach triady mogą być przegłosowane w dowolnej sprawie przez koalicję dwóch pozostałych członków. Dana osoba może zagrozić zerwaniem relacji diadycznej przez wycofanie się. Takie zagrożenia są mniejsze w triadach, biorąc pod uwagę, że zawsze będą dwie osoby skłonne kontynuować relację. Konflikt w triadach między dwojgiem ludzi można złagodzić i naprawić poprzez interwencję trzeciej osoby ${ }^{7}$. Diady osadzone w klikach są bardziej ograniczone w swoich postawach i zachowaniu niż diady niezależne od klik. Niektóre diady są osadzone w wielu klikach i dlatego podlegają normom wszystkich tych klik. W badaniach Krackhardta i Kilduffa ${ }^{8}$ w sieciach porad i przyjaźni osoby w diadach simmeliańskich (w porównaniu do diad w ogóle) osiągają wyższe porozumienie co do tego, kto jest z kim związany i kto jest osadzony razem w triadach w organizacjach.

Kontekstem teoretycznym dla tych badań jest również teoria działalności ${ }^{9}$ ukierunkowana na zrozumienie złożonej dynamiki zbiorowego wysiłku człowieka. W centrum uwagi jest system działalności, który tworzą powiązane i współzależne elementy, takie jak: narzędzia, podmiot, przedmiot, zasady, podział pracy, społeczność oraz rezultat. Tworzona wartość, kluczowe praktyki i procesy zależą zatem od indywidualnych działań aktorów społecznych organizacji, grup i sieci osób. Tu działalność stanowić będą celowe interakcje pomiędzy podmiotami (aktorami społecznymi), obiektami (przedmiotami) i narzędziami (zasobami), co jest

5 D. Krackhardt, Simmelian tie: Super strong and sticky, [w:] R.M. Kramer, M.A. Neale (red.), Power and influence in organizations, Sage, Thousand Oaks 1998, s. 21-38.

6 G. Simmel, The sociology of Georg Simmel, Free Press, New York 1950, s. 135-142.

7 D. Krackhardt, The ties that torture: Simmelian tie analysis in organizations, „Research in the Sociology of Organizations" 1999, vol. 16, no. 1, s. 183-210.

8 D. Krackhardt, M. Kilduff, Structure, culture and Simmelian ties in entrepreneurial firms, „Social Networks" 2002, vol. 24, no. 3, s. 279-290.

9 Zob. F. Blackler, Knowledge and the theory of organizations: Organizations as activity systems and the reframing of management, „Journal of Management Studies” 1993, vol. 30, no. 6, s. 863-884; Y. Engestrom, Activity theory as a framework for analyzing and redesigning work, „Ergonomics” 2000, vol. 43, no. 7, s. 960-974; G. Holt, A. Morris, Activity theory and the analysis of organizations, „Human Organization” 1993, vol. 52, no. 1, s. 97-109. 
też istotą metasieciowego ujęcia organizacji. Teoria zasobowa ${ }^{10}$ uzupełnia ten kontekst teoretyczny, w którym zasoby (w tym konkurencyjne) postrzegane są w powiązaniu z działaniami, aktywnością aktora społecznego, który potrafi je produktywnie wykorzystać do tworzenia wartości w organizacji.

Teoria złożoności ${ }^{11} \mathrm{w}$ kontekście organizacyjnym zakłada, że organizacje są tworzone przez złożone sieci relacji, które reagują w sposób dynamiczny na wewnętrzne i zewnętrzne naciski oraz konteksty. Złożoność zachodzi poprzez relacje w sieciach, w których jednostki wpływają na innych, a ci z kolei wpływają na pozostałych w obrębie sieci. Jednym z najbardziej podstawowych elementów teorii złożoności jest znaczenie interakcji między jednostkami i złożonymi systemami adaptacyjnymi (organizacje), rozumianymi jako agregaty mające zdolność adaptacji. Wymaganą złożoność można zaobserwować, mierząc napięcie adaptacyjne w systemie, patrząc na różnorodność odpowiedzi w porównaniu z różnorodnością bodźca (np. dodanie i/lub usunięcie węzła i/lub relacji) ${ }^{12}$. Przykładowo: zasoby są z natury ograniczone, decyzje dotyczące ich alokacji, dostarczania zbyt dużej lub zbyt małej ilości mogą radykalnie wpłynąć na system. Symulacja elementów może przewidywać zmiany celowe i przypadkowe, patrząc na sieć jako złożony system adaptacyjny, w którym uczenie odbywa się poprzez interakcję i zmiany ${ }^{13}$. Interakcja dotyczyć może przepływu informacji (wspólne rozwiązywanie problemów), który jest zależny od stopnia, w jakim ludzie dzielą się informacjami i wiedzą w wykonywaniu zadań. Interakcja i współzależność są zatem czynnikami napędzającymi dynamikę systemu społeczno-technicznego, w którym dominującą rolę odgrywają oddziałujące na siebie elementy społeczne i techniczne ${ }^{14}$.

10 Zob. J.B. Barney, Resource-based theories of competitive advantage: A ten-year retrospective on the resource-based view, „Journal of Management” 2001, vol. 27, no. 6, s. 643-650; Q. Wang, S. Gao, Network architecture and firm performance: A resources-based view, „Frontiers of Business Research in China” 2011, vol. 5, no. 4, s. 559-579; N. Wills-Johnson, The networked firm: A framework for RBV, „The Journal of Management Development” 2008, vol. 27, no. 2, s. 214-224.

11 Zob. P. Anderson, Complexity theory and organization science, „Organization Science” 1999, vol. 10, no. 3, s. 216-232; R.D. Stacey, The science of complexity: An alternative perspective for strategic change processes, „Strategic Management Journal” 1995, vol. 16, no. 6, s. 477-495; N. Papastefanou, A complexity theory-based management framework for virtual organizations, „African Journal of Business Management” 2010, vol. 4, no. 11, s. 2323-2337; P. Cilliers, What can we learn from a theory of complexity?, „Emergence” 2000, vol. 2, no. 1, s. 23-33.

12 Więcej na temat teorii złożoności w kontekście organizacyjnym zob. A. Ujwary-Gil, Network theory and complexity theory in the context of organization and management sciences, [w:] A. Ujwary-Gil, N.R. Potoczek (red.), Network, innovation and competence-based economy, Instytut Nauk Ekonomicznych Polskiej Akademii Nauk, Warszawa 2019, s. 79-97.

13 K.M. Carley, L. Gasser, Computational organization theory, [w:] G. Weiss (red.), Multiagent systems: A modern approach to distributed artificial intelligence, MIT Press, Cambridge 1999, s. 299-330.

14 A. Ujwary-Gil, Audyt zasobów niematerialnych... 
Newman ${ }^{15}$ stwierdził, że złożony system to taki, który składa się z wielu współdziałających części, często zwanych agentami. Wykazuje on wysoki stopień systemowej współzależności, co prowadzi między innymi do nieliniowości, tworzenia nowego porządku i innej zaskakującej dynamiki. Złożone systemy organizują się od wewnątrz, wspólnie reagując i dostosowując się do bodźców zewnętrznych względem granicy systemu, jakim jest organizacja. Termin „złożony system adaptacyjny"16 jest często używany jako metafora w celu przeciwdziałania bardziej mechanistycznemu opisowi organizacji jako maszyny ${ }^{17}$. Odnosi się on do otwartych systemów dynamicznych, które są w stanie samoorganizować się poprzez wymianę informacji, energii i innych zasobów w swoim środowisku, przekształcać zasoby w działania ${ }^{18}$. Samoorganizacja to proces, w którym elementy systemu spontanicznie komunikują się ze sobą i współpracują w skoordynowanym wspólnym zachowaniu ${ }^{19}$. Dzięki samoorganizacji zachowanie grupy wyłania się z kolektywnych interakcji wszystkich osób. Zasady samoorganizacji generują nowe podejście do zarządzania, ponieważ nacisk kładziony jest na przystosowanie się do szybkich i ciągłych zmian. Konsekwencją tego jest przesunięcie kluczowych kwestii zarządczych od utrzymania kontroli do wspierania pojawienia się nowych zasad zarządzania, opartych na wzajemnych zależnościach między aktorami. Wszystkie złożone systemy adaptacyjne są utrzymywane przez przepływ energii (np. informacji, wiedzy) oraz zasobów z otoczenia. Wysoki poziom interaktywności jest niezbędny do koordynacji, która odbywa się w rozległych sieciach komunikacyjnych. Poprzez interakcję wiedza jest pozyskiwana, tworzona lub dzielona, a informacje są rozpowszechniane w celu zapewnienia produktywności i wydajności ${ }^{20}$. W teorii złożoności organizacja opiera się zatem na wzorcach relacji między aktorami. Kto się z kim komunikuje, w dużej mierze zależy od zadań będących w trakcie realizacji. Wzorce relacji powstają w wyniku synergii utworzonej między aktorami, postrzeganymi jako komponenty systemu.

Powyższe rozważania teoretyczne rzucają nieco światła na cechy systemu społeczno-technicznego, jakim jest organizacja, rozumiana tutaj również jako złożony

15 M. Newman, Networks: An introduction, Oxford University Press, Oxford 2010.

16 M. Gell-Mann, The quark and the jaguar: Adventures in the simple and the complex, Macmillan, New York 1995.

17 G. Morgan, Images of organization, Sage, Thousand Oaks 1996.

18 C. Larson, Evidence of shared aspects of complexity science and quantum phenomena. Cosmos and History, „The Journal of Natural and Social Philosophy” 2016, vol. 12, no. 2, s. 160-171.

19 R.D. Stacey, The science of complexity...

20 A. Ujwary-Gil, Organizational network analysis: A study of a university library from a network efficiency perspective, „Library \& Information Science Research” 2019, vol. 41, no. 1, s. 48-57. 
system adaptacyjny powiązany zbiorem współzależnych i oddziałujących na siebie relacji (interakcji) między aktorami społecznymi (pracownicy) a aktorami pozaspołecznymi (wiedza, zasób, działanie).

\section{Metodyka badań wtasnych}

\section{Studium przypadku i respondenci}

Badania sieciowe na tle innych badań społecznych wyróżnia pozyskiwanie i zarządzanie danymi sieciowymi (poufność danych, brak anonimowości, etyka badań sieciowych), cechy danych sieciowych (współzależność), poziom analiz (cała sieć, diada, pojedynczy węzeł) i zmienne sieciowe przyjmujące postać macierzy. Dane sieciowe pozyskano w pierwszym kwartale 2017 roku w przedsiębiorstwie sektora informatycznego zatrudniającym w tym czasie 47 pracowników (aktorów społecznych w ujęciu sieciowym), na podstawie kwestionariusza ankiety generowanej on-line. Dobór przypadku do badań miał charakter celowy, kierowano się przy tym kryterium związanym ze znaczeniem wiedzy i dojrzałością strategiczną organizacji, które zwiększają prawdopodobieństwo dostrzeżenia poszukiwanych zasobów niematerialnych i ich związków z tworzeniem wartości i strategii. Dodatkowym kryterium przy doborze celowym było kryterium dostępności ${ }^{21}$. Podstawą opracowania ankiety badawczej był wywiad przeprowadzony z dyrektorem Działu Wdrożeń, który dotyczył (obok wielu innych zagadnień) identyfikacji i analizy elementów procesów biznesowych przedsiębiorstwa z podziałem na wiedzę, zasoby i zadania. W badaniu wzięło udział w sumie 45 pracowników, co stanowiło $98 \%$ populacji, eliminując tym samym problem brakujących danych (węzłów), które w badaniach sieciowych są dość problematyczne. Średnia liczba lat doświadczenia zawodowego ogółem wyniosła 10,20, odchylenie standardowe 7,14, wartość minimalna to rok, a maksymalna 35 lat.

\section{Zmienne i mierniki sieciowe}

Podstawą analiz jest identyfikacja rodzajów relacji, które tworzą następujące macierze i które będą stanowić podstawę wymienionych mierników sieciowych:

- $A A_{i j}{ }^{1}$ (aktor/aktor) - wspólne rozwiązywanie problemów;

- $A A_{i j}^{2}$ (aktor/aktor) - doświadczenie ogółem (liczba lat zatrudnienia);

21 J.W. Creswell, C.N. Poth, Qualitative inquiry and research design: Choosing among five approaches, Sage, London 2017. 
- $A R_{i j}$ (aktor/zasób) - wykorzystanie zasobu $j$ przez aktora $i$;

- $A T_{i j}$ (aktor/zadanie) - wykonywane zadanie $j$ przez aktora $i$;

- $R T_{i j}$ (zasób/zadanie) - zasób $i$ kluczowy do realizacji zadania $j$.

W macierzach związek między węzłami wierszy a węzłami kolumn konstytuują silne relacje. W macierzy $A A_{i j}{ }^{1}$ aktor $i$ kontaktuje się z aktorem $j \mathrm{w}$ celu uzyskania pomocy w rozwiązywaniu złożonych problemów związanych $\mathrm{z}$ wykonywaną pracą przynajmniej raz na dzień lub raz na tydzień. Macierz $A A_{i j}{ }^{2}$ określono na podstawie różnicy w liczbie lat doświadczenia zawodowego ogółem między aktorami wierszy i kolumn macierzy. Pozostałe macierze stanowią odpowiedź respondentów dotyczącą wykorzystywanej przez nich wiedzy $(K)$, zasobów $(R)$ i wykonywanych zadań $(T)$ z dostępnej listy, która powstała na podstawie zidentyfikowanych w wywiadzie procesów biznesowych przedsiębiorstwa informatycznego ${ }^{22}$. W sumie określono 47 węzłów $K$ (wiedzy i umiejętności), 18 węzłów $R$ (zasobów, narzędzi), 48 węzłów $T$ (zadań, aktywności). Poziomem analizy są poszczególni aktorzy $(A)$ oraz diady (pary węzłów), czyli relacje między dwoma aktorami.

Zmiennymi sieciowymi (zob. tabela 1) dla poszczególnych aktorów $i$ (pracowników) są $C D_{i}$ (cognitive demand), $S T_{i}$ (Simmelian tie), $S S A_{i}$ (shared situation awareness) oraz sieć $A A_{i j}{ }^{2}$ (doświadczenie zawodowe).

Tabela 1. Mierniki sieciowe wykorzystane w badaniu

\begin{tabular}{|c|c|c|}
\hline $\begin{array}{l}\text { Miernik/ } \\
\text { Zmienna } \\
\text { sieciowa }\end{array}$ & Wzór & Opis \\
\hline $\begin{array}{l}\text { Integracja } \\
\text { zadaniowa } \\
\left(C D_{i}\right)\end{array}$ & $\begin{array}{l}C D_{i}=\left(x_{1}+x_{2}+x_{3}+x_{4}+x_{5}\right) / 5 \\
x_{1}=\left(\sum_{j \neq i} A(i, j)\right) /(|A|-1) \\
x_{2}=\operatorname{suma}(A T(i,:)) /|T| \\
x_{3}=\left(\sum_{j \neq i} A T A(i, j)\right) /(|A|-1)(|T|) \\
x_{4}=\operatorname{suma}(\operatorname{AR}(\mathrm{i},:)) /|R| \\
x_{5}=\operatorname{suma}(A T R(\mathrm{i},:)) /\left(|T|^{*}|R|\right) \\
\text { gdzie: } \\
\text { ATR }=A T^{\star} R T^{\prime} \\
\text { ATA }=A T^{\star} A T^{\prime}\end{array}$ & $\begin{array}{l}\text { Mierzy łączny nakład pracy, } \\
\text { wykorzystanych zasobów } \\
(R) \text { przez każdego aktora }(A) \\
\text { do wykonania przez niego } \\
\text { zadań }(T) \text {. } \\
R T \text { ' oraz } A T^{\prime} \text { oznaczają } \\
\text { transpozycję macierzy. }\end{array}$ \\
\hline
\end{tabular}

22 Szczegółowa identyfikacja tych węzłów znajduje się w publikacji A. Ujwary-Gil, Audyt zasobów niematerialnych..., s. 172-173. 
Tabela 1 (cd.)

\begin{tabular}{|c|c|c|}
\hline $\begin{array}{l}\text { Miernik/ } \\
\text { Zmienna } \\
\text { sieciowa }\end{array}$ & Wzór & Opis \\
\hline $\begin{array}{l}\text { Więzi } \\
\text { simmeliańskie } \\
\left(S T_{i}\right)\end{array}$ & $\begin{array}{l}S T \text { - niech } A \text { będzie unimodalną, } \\
\text { binarną siecią wejściową; wszystkie kliki } \\
\text { o rozmiarze >= } 3 \text {; niech } N_{i} \text { będzie liczbą } \\
\text { odrębnych węzłów znajdujących się } \\
\text { w klice z węztem } i \text {; } S T \text { dla węzła } i=N_{i} /(N \\
\text { - 1), gdzie } N \text { jest liczbą węzłów w sieci } A \text {. }\end{array}$ & $\begin{array}{l}\text { Dwa węzły są simmeliańskie, } \\
\text { jeśli są wzajemnie i silnie } \\
\text { powiązane ze sobą i powiązane } \\
\text { z co najmniej jedną wspólną } \\
\text { stroną trzecią. Nieformalnie } \\
\text { określane są jako więzy } \\
\text { osadzone w klikach i często } \\
\text { kojarzone z pośrednikami } \\
\text { wewnątrz takich klik; jeśli } \\
\text { aktor A01 i A02 znają się tylko } \\
\text { ze względu na A03, a teraz A01, } \\
\text { A02 i A03 znają się, to mają } \\
\text { podobne do siebie więzy. }\end{array}$ \\
\hline $\begin{array}{l}\text { Wspólna } \\
\text { świadomość } \\
\text { sytuacji }\left(S S A_{i}\right)\end{array}$ & 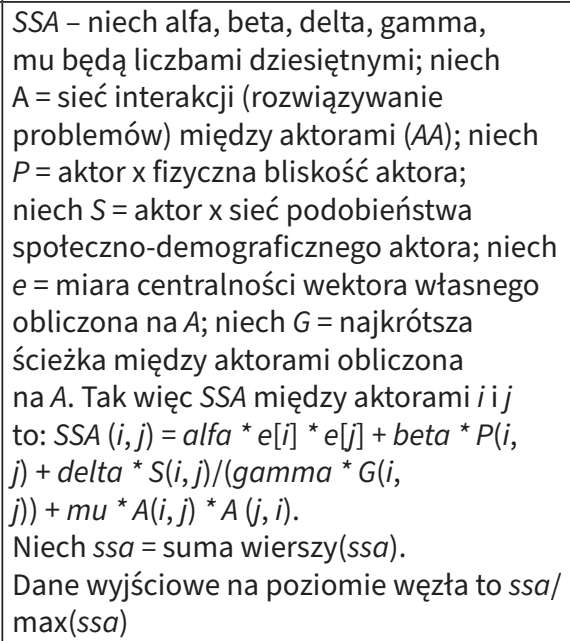 & $\begin{array}{l}\text { Osoby lub organizacje, które } \\
\text { mają dużą świadomość grupową, } \\
\text { to te, które - z racji swoich } \\
\text { powiązań z innymi - wiedzą, } \\
\text { z jakich zasobów korzystają } \\
\text { inni, jaka jest ich wiedza, jakie } \\
\text { są ich zadania - lepiej rozumieją, } \\
\text { co robią inni. }\end{array}$ \\
\hline
\end{tabular}

Źródto: opracowanie własne na podstawie K.M. Carley, J. Reminga, ORA: Organization Risk Analyzer, Carnegie-Mellon University, Pittsburgh 2004 oraz K.M. Carley i wsp., ORA user's guide, Carnegie-Mellon University, Pittsburgh 2018.

\section{Wyniki badań i dyskusja}

Rysunek 1 obrazuje relacje między aktorami (tzw. najmniej zintegrowanymi zadaniowo i społecznie) wymienionymi w tabeli $2\left(A A_{i j}{ }^{1}\right)$ dla macierzy 'wspólne rozwiązywanie problemów', a rysunek 2 relacje między aktorami a wykonywanymi zadaniami $\left(A T_{i j}\right)$. 
Metasieciowe ujęcie organizacji IT... 161

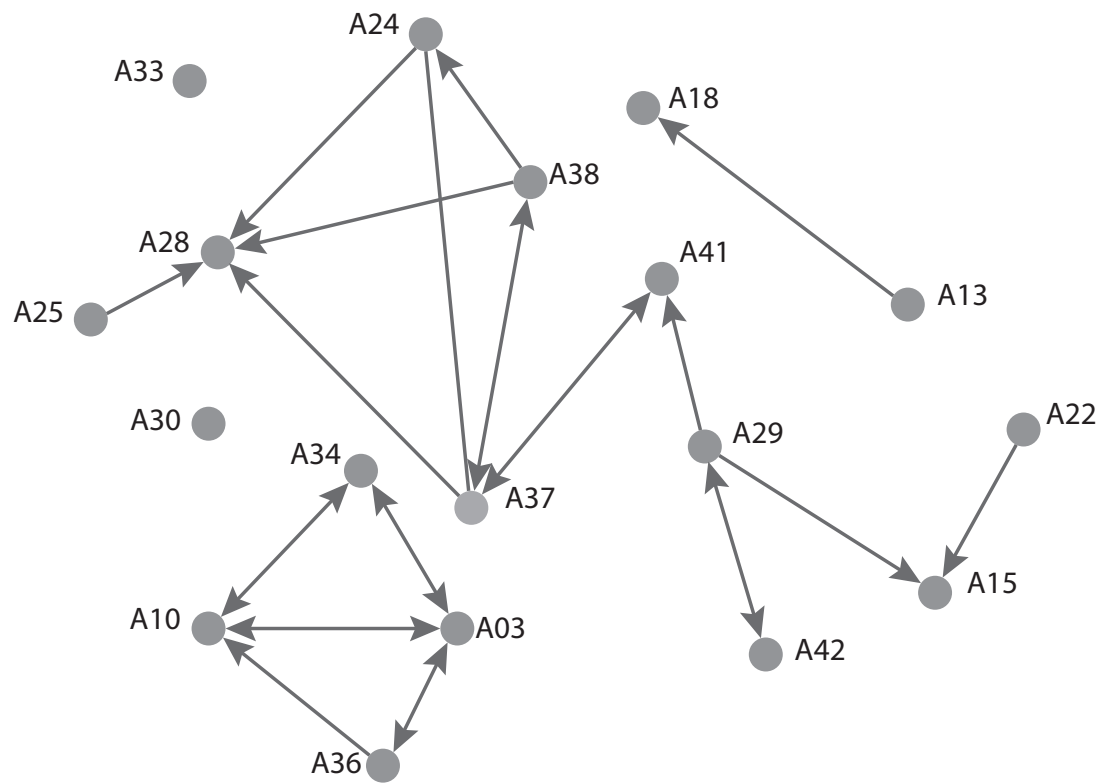

Rysunek 1. Sieci relacji aktor/aktor $\left(A A_{i j}{ }^{1}\right)$

Źródto: opracowanie własne.

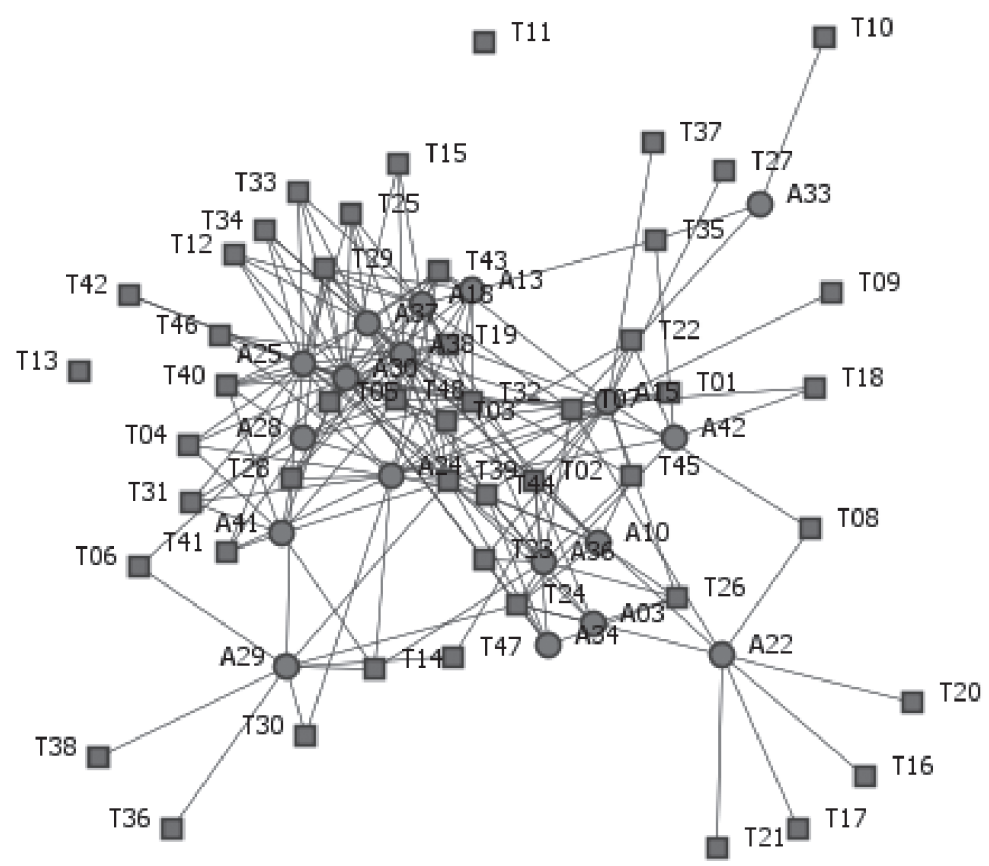

Rysunek 2. Sieci relacji aktor/zadanie $\left(A T_{i j}\right)$ Źródto: opracowanie własne. 
Tabela 2 zawiera prezentację zanonimizowanych aktorów (respondentów, tu pracowników przedsiębiorstwa informatycznego) na podstawie najniższych (standaryzowanych według wielkości sieci, czyli liczby pracowników) wartości mierników sieciowych.

Tabela 2. Ranking peryferyjnych aktorów z punktu widzenia ich pozycji w sieci23

\begin{tabular}{|c|c|c|c|c|c|c|c|c|c|c|c|c|}
\hline R. & \multicolumn{2}{|c|}{ Aktor } & \multicolumn{2}{|c|}{$C D$} & \multicolumn{2}{|c|}{ Aktor } & \multicolumn{2}{|c|}{ ST } & \multicolumn{2}{|c|}{ Aktor } & \multicolumn{2}{|c|}{ SSA } \\
\hline 1. & \multicolumn{2}{|c|}{ A33 } & \multicolumn{2}{|c|}{0,136} & \multicolumn{2}{|c|}{ A15 } & \multicolumn{2}{|c|}{0} & \multicolumn{2}{|c|}{$A 28$} & \multicolumn{2}{|c|}{0,010} \\
\hline 2. & \multicolumn{2}{|c|}{$A 03$} & \multicolumn{2}{|c|}{0,139} & \multicolumn{2}{|c|}{ A18 } & \multicolumn{2}{|r|}{0} & \multicolumn{2}{|c|}{ A33 } & \multicolumn{2}{|c|}{0,010} \\
\hline 3. & \multicolumn{2}{|c|}{ A34 } & \multicolumn{2}{|c|}{0,141} & \multicolumn{2}{|c|}{$A 22$} & \multicolumn{2}{|r|}{0} & \multicolumn{2}{|c|}{$A 22$} & \multicolumn{2}{|c|}{0,012} \\
\hline 4. & \multicolumn{2}{|c|}{ A22 } & \multicolumn{2}{|c|}{0,176} & \multicolumn{2}{|c|}{ A25 } & \multicolumn{2}{|r|}{0} & \multicolumn{2}{|c|}{ A18 } & \multicolumn{2}{|c|}{0,013} \\
\hline 5. & \multicolumn{2}{|c|}{ A10 } & \multicolumn{2}{|c|}{0,178} & \multicolumn{2}{|c|}{$A 28$} & \multicolumn{2}{|r|}{0} & \multicolumn{2}{|c|}{ A34 } & \multicolumn{2}{|c|}{0,014} \\
\hline 6. & & 36 & & & & 30 & & 0 & & 10 & & 14 \\
\hline 7. & & 13 & & & & 33 & & 0 & & 25 & & 14 \\
\hline 8. & & 42 & & & & 37 & & 0 & & 30 & & 15 \\
\hline 9. & & & & & & 38 & & 0 & & 03 & & 15 \\
\hline 10. & & 41 & & & & 41 & & 0 & & 24 & & 16 \\
\hline SO & Min: & 0,136 & M: & 0,268 & Min: & 0 & M: & 0,088 & Min: & 0,010 & M: & 0,022 \\
\hline & Max: & 0,427 & SD: & 0,063 & Max: & 0,341 & SD: & 0,074 & Max: & 0,052 & SD: & 0,008 \\
\hline
\end{tabular}

Objaśnienia: R. - ranking aktorów o najniższych wartościach zmiennych

sieciowych; A - aktor; CD - integracja zadaniowa; ST - więzi simmeliańskie; SSA

- wspólna świadomość sytuacji; SO - statystki opisowe; Min - wartość minimalna;

Max - wartość maksymalna; M - średnia; SD - odchylenie standardowe.

Źródło: opracowanie własne na podstawie ORA-PRO, wersja 3.0.9.9.87, Carnegie Mellon University, School of Computer Science, Institute for Software Research, Pittsburgh 2018.

Prezentację wyników ograniczono do pierwszych dziesięciu aktorów, pokrótce scharakteryzowanych na podstawie ich powiązania z zadaniami $(T)$, jak zaznaczono w zmiennej $C D$. Są tu pracownicy, którzy piastują różne stanowiska, wynikające ze specyfiki firmy zajmującej się zaawansowanymi rozwiązaniami IT dla biznesu (np. starszy programista, specjalista ds. administracyjnych, konsultant ds. wdrożeń czy konsultant ds. telefonicznej obsługi klientów). W przypadku zmiennej ST wśród wymienionych pracowników znajduje się między innymi pracownik Działu Handlowego, konsultant ds. wdrożeń, specjalista ds. marketingu czy księgowości, programista, jak również konsultant ds. administracyjnych. Dla zmiennej $S S A$ w tej grupie znaleźli się między innymi programista, konsultant ds. wdrożeń, konsultant ds. telefonicznej obsługi klientów, specjalista ds. księgowości czy marketingu.

Pytanie badawcze 1. Którzy aktorzy są najmniej zintegrowani zadaniowo w sieci organizacyjnej?

23 Wiersz jest kursywą, jeśli węzet ma wartość niższą niż normalna (mniej niż jedno odchylenie standardowe poniżej średniej). Wiersz jest pogrubiony, jeśli węzet mieści się w zakresie jednego odchylenia standardowego od średniej. 
Aktorzy najmniej zintegrowani zadaniowo to A33, A03, A34, A22, A10, A36, A13, A42, A29 oraz A41 według najniższej wartości dla CD. Przykładowo: na podstawie macierzy relacji $A T_{i j}$ (aktor/zadanie) aktor A33 deklaruje wykonywanie zadania T7 (kreowanie wizerunku badanej firmy), T10 (obsługa klientów spółki księgowej) oraz T35 (sprawozdawczość przed urzędami). Aktor A03 wykonuje zadanie T2 (analiza potrzeb klienta), T24 (przekazanie zainteresowanego klienta do działu handlowego), T26 (przygotowanie bazy potencjalnych klientów), T39 (telefoniczny kontakt z klientem) oraz T44 (wprowadzenie i/lub wyszukiwanie klientów w bazie). Pozostali aktorzy wykonują od 6 do 10 zadań na 48 powiązanych z procesami biznesowymi zadań badanego przedsiębiorstwa. Wymienieni powyżej aktorzy w sieci macierzy relacji $A A_{i j}{ }^{1}$ (aktor/aktor), odnoszącej się do wspólnego rozwiązywania złożonych problemów związanych z pracą (silne relacje między pracownikami w tym obszarze, tzn. przynajmniej raz dziennie lub raz na tydzień), odnotowali następujące relacje: aktor A33 wspólnie rozwiązuje złożone problemy głównie z aktorem A32. Aktor A03 nawiązuje tego typu relacje głównie $\mathrm{z}$ aktorami A10, A34, A36 i A39. Pozostali aktorzy (A34, A22, A10, A36, A13, A42, A241) odnotowali od 2 do 7 wychodzących relacji tego typu, z wyjątkiem aktora A29 (19 relacji).

Podstawowym założeniem tego miernika sieciowego było wskazanie aktorów najmniej zintegrowanych zadaniowo w kontekście ich wysiłków do wykonywania zadań, powiązań z innymi aktorami z tytułu wspólnego rozwiązywania problemów, dyskutowania rozwiązań na podstawie pozycji danej osoby w metasieci. Osoby współpracujące w ramach organizacji są bardziej skuteczne, gdy dysponują informacjami niezbędnymi do wykonania ich indywidualnych zadań. Osoby najmniej zintegrowane zadaniowo będą powiązane z niewielką liczbą aktorów, zadań, dziedzinami wiedzy i zasobami; mniej będą angażować się w złożone zadania, do realizacji których mogą nie mieć wszystkich potrzebnych zasobów lub wiedzy.

Pytanie badawcze 2. Którzy aktorzy są najmniej powiązani społecznie w sieci organizacyjnej?

Aktorzy najmniej powiązani społecznie (ST) to A15, A18, A22, A25, A28, A30, A33, A37, A38 oraz A41, których wartość wynosi 0. Oznacza to, że nie mają oni więzi typu simmeliańskiego. Simmel ${ }^{24}$ argumentował, że triady są podstawową jednostką analizy socjologicznej. Trzech aktorów triady cechuje jakościowo odmienna dynamika społeczna, której nie można sprowadzić do jednostek lub diad, gdzie bezpośrednie powiązanie między dwoma aktorami zmienia się w obecności trzeciego aktora. Według Colemana ${ }^{25}$ zamknięcie triad prowadzi do zaufania interpersonalnego, większej współpracy i egzekwowania norm. Argument ten można uogólnić do poziomu

24 G. Simmel, The sociology...

25 J.S. Coleman, Foundation of social theory, Harvard University Press, Cambridge 1990. 
współpracy w grupach w zależności od struktury sieci. Zamknięta triada istnieje, gdy wszyscy jej członkowie są powiązani daną relacją. Powiązanie strony trzeciej służy ograniczeniu indywidualnych interesów na korzyść interesów zbiorowych, ograniczeniu indywidualnej siły przetargowej oraz zapobieganiu eskalacji konfliktów (możliwa jest mediacja strony trzeciej) ${ }^{26}$. Relacje między dwoma aktorami dzielącymi wspólną więź strony trzeciej są bardziej oparte na współpracy, trwałe i zgodne niż izolowana diada - z powodu roli strony trzeciej w pośredniczeniu w konflikcie czy sankcjonowaniu zachowań oportunistycznych. Więzi simmeliańskie ograniczają interes własny i zachowania oportunistyczne, takie jak brak wymiany poufnych informacji między sobą. Ponadto więzi osadzone w spójnych klikach mają zwiększone prawdopodobieństwo dzielenia się wiedzą 27. Przywołani aktorzy (zob. kolumny: Aktor i ST w tabeli 2) są najmniej powiązani społecznie z punktu widzenia ich obecności w triadzie - ze wszystkimi tego pozytywnymi i negatywnymi konsekwencjami.

Pytanie badawcze 3. Którzy aktorzy mają najniższą świadomość sytuacji w sieci organizacyjnej?

Osoby lub organizacje, które mają dużą świadomość grupową, to te, które - z racji swoich powiązań z innymi - wiedzą, z jakich zasobów korzystają inni, jaka jest ich wiedza, jakie są ich zadania - lepiej rozumieją, co robią inni. W tym przypadku aktorzy A28, A33, A22, A18, A34, A10, A25, A30, A03 oraz A24 charakteryzują się najniższą świadomością sytuacji (są najmniej zorientowani, co dzieje się w organizacji) na podstawie interakcji społecznych (rozwiązywanie problemów) między dwoma aktorami, dystansu fizycznego, danych społeczno-demograficznych aproksymowanych przez ich wspólną wiedzę $(K)$ i zasoby $(R)$. Najmniej świadome osoby w organizacji mogą tworzyć tzw. silosy informacyjne, które są źródłem słabej komunikacji i powielania rozwiązywania problemów, a ich istnienie może udaremnić wysiłki w zakresie zmian organizacyjnych ${ }^{28}$. Niższe wartości miernika SSA (zob. tabela 1) mogą oznaczać w tym przypadku, że w organizacji są osoby, które nie wiedzą, co robią inni, nie podzielają zrozumienia problemów, przed którymi stoi organizacja. Niższe wartości mogą oznaczać słabszą integrację pracowników, która zwykle umożliwia szybkie rozpoznawanie błędów i łagodzenie niezamierzonych konsekwencji.

26 J.R. Hollenbeck, B.B. Jamieson, Human capital, social capital, and social network analysis: Implications for strategic human resource management, „Academy of Management Perspectives" 2015 , vol. 29 , no. 3 , s. 370-385.

27 K. Huang, Knowledge sharing in a third-party-governed health and human services network, „Public Administration Review” 2014, vol. 74, no. 5, s. 587-598.

28 J. Merrill, J.W. Keeling, K.M. Carley, A comparative study of 11 local health department organizational networks, „Journal of Public Health Management and Practice” 2010, vol. 16, no. 6 , s. 564-576. 

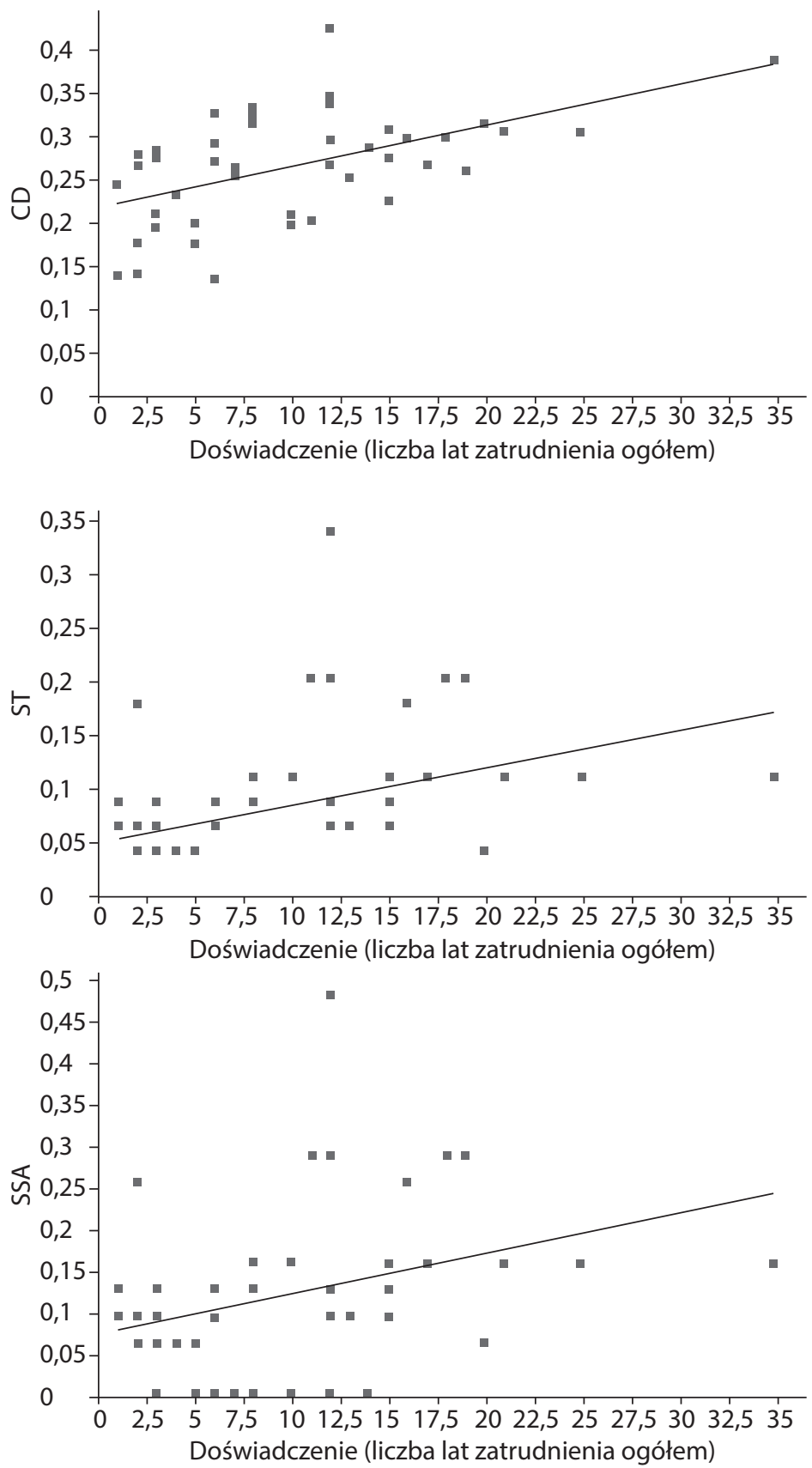

Rysunek 3. Zależności między zmiennymi sieciowymi (doświadczeniem zawodowym, CD, ST oraz SSA)

Źródto: opracowano na podstawie ORA-PRO, wersja 3.0.9.9.87. 
Pytanie badawcze 4. Czy doświadczenie mierzone liczbą lat pracy może mieć wpływ na pozycję aktora w sieci?

Aby wskazać poziom korelacji między siecią $A A_{i j}{ }^{2}$ a $C D_{i}$, siecią $A A_{i j}{ }^{2} a S T_{i}$ oraz siecią $A A_{i j}{ }^{2}$ a $S S A_{i}$, wykorzystano wykresy punktowe. Rysunek 3 obrazuje zależności między aktorami społecznymi, szczególnie ich doświadczeniem zawodowym mierzonym liczbą lat pracy ogółem, a określonymi dla potrzeb tych badań zmiennymi sieciowymi (CD, ST, $S A A)$.

Wykresy punktowe pokazały, że liniowa korelacja ( $r$ ) Pearsona między zmiennymi: doświadczenie i $C D$ jest na wysokim poziomie (według notacji Guilforda ${ }^{29}$ ) i wynosi $r=0,5241, r^{2}=0,2746, M=0,0046, b=0,2204$. Zależność ta jest istotna statystycznie $p<0,001$. Dla zmiennych doświadczenie i ST korelacja jest przeciętna $r=0,3272, r^{2}=0,1071, M=0,0034$, a $b=0,0530$. Zależność jest istotna statystycznie $p=0,028$. Zależność między doświadczeniem a $S S A$ jest również przeciętna i wynosi $r=0,3247, r^{2}=0,1054, M=3,4682, b=0,0186$, a $p=0,030$.

Interpretacja siły związku jest mniej ważna niż informacja, czy dana zależność jest istotna statystycznie. Wszystkie korelacje (doświadczenie a CD, ST i SAA) są istotne na standardowym poziomie istotności $p<0,05$, przy czym jedne są silniejsze, a inne słabsze. Możemy zauważyć, że według przyjętego poziomu istotności uzyskana wartość jest dziełem prawdziwej zależności, co nie wyklucza wpływu innych zmiennych, które nie zostały tutaj określone.

\section{Podsumowanie}

Na podstawie niniejszych badań ustalono, którzy aktorzy (pracownicy) zajmują peryferyjną pozycję w sieci społecznej. Wskazano aktorów najmniej zintegrowanych zadaniowo $(C D)$, najmniej powiązanych społecznie $(S T)$ oraz o najniższej świadomości sytuacji (SAA) w wybranym do badań przedsiębiorstwie IT. Ocena peryferyjnych aktorów, ich zachowań (głównie na podstawie wykonywanych zadań, częstotliwości relacji w ramach macierzy 'wspólne rozwiązywanie problemów') oraz poziomu efektywności z punktu widzenia osiąganych rezultatów w miejscu pracy wymaga pogłębionych analiz, również pod kątem optymalnego ich wykorzystania. Prezentowane badania ograniczyły się do dwóch głównych relacji: wykonywanych przez pracowników zadań $\left(A T_{i j}\right)$ oraz wspólnego rozwiązywania złożonych problemów związanych z wykonywaną pracą $\left(A A_{i j}{ }^{1}\right)$, na których opierają się zmienne sieciowe wymienione w tabeli 1 .

29 J.P. Guilford, Fundamental statistics in psychology and education, McGraw-Hill College, New York 1977. 
Ustalono, że istnieje statystycznie istotna zależność między liczbą lat doświadczenia ogółem a integracją zadaniową pracowników $(C D)$. Odnotowano przeciętną siłę związku, istotną statystycznie, między doświadczeniem zawodowym a $S T$ i $S A A$. Obserwowany związek między dwiema zmiennymi na wykresach punktowych może oznaczać, że zmiany w jednej zmiennej są odpowiedzialne za zmiany w drugiej. Współczynnik determinacji $r^{2}$ jest na stosunkowo niskim poziomie i wynosi $27 \%$ dla $C D, 11 \%$ dla $S T$ oraz $10 \%$ dla $S S A$. Aby ustalić interesujący nas związek, należy przeprowadzić dalszą analizę w celu kontroli lub uwzględnienia efektów innych potencjalnych zmiennych (np. wieku, płci, doświadczenia zawodowego w tej konkretniej spółce, a nawet zajmowanego stanowiska czy specyfiki wykonywanych zadań), aby wykluczyć inne możliwe wyjaśnienia. Dalsze badania powinny koncentrować się na identyfikacji konstruktywnych relacji dla organizacji i ludzi w niej zatrudnionych, w powiązaniu z efektywnością procesów biznesowych, na podstawie których określono podstawowe węzły sieci intraorganizacyjnej.

\section{Bibliografia}

Anderson P., Complexity theory and organization science, „Organization Science” 1999, vol. 10, no. 3, s. 216-232.

Austen A., Efektywność sieci publicznych. Podejście wielopoziomowe, Wydawnictwo C.H. Beck, Warszawa 2014.

Barabási A.-L., Network theory - the emergence of the creative enterprise, „Science” 2005, vol. 308, no. 5722, s. 639-641.

Barney J.B., Resource-based theories of competitive advantage: A ten-year retrospective on the resource-based view, „Journal of Management” 2001, vol. 27, no. 6, s. 643-650.

Blackler F., Knowledge and the theory of organizations: Organizations as activity systems and the reframing of management, „Journal of Management Studies” 1993, vol. 30, no. 6, s. 863-884.

Borgatti S.P., Halgin D.S., On network theory, „Organization Science” 2011, vol. 22, no. 5, S. $1168-1181$.

Burt R.S., Gabbay S. M., Holt G., Moran P., Contingent organization as a network theory: The culture-performance contingency function, „Acta Sociologica” 1994, vol. 37, no. 4, s. 345-370.

Carley K.M., Gasser L., Computational organization theory, [w:] G. Weiss (red.), Multiagent systems: A modern approach to distributed artificial intelligence, MIT Press, Cambridge 1999, s. $299-330$.

Carley K.M., Reminga J., ORA: Organization Risk Analyzer, Carnegie-Mellon University, Pittsburgh 2004.

Carley K.M., Pfeffer J., Reminga J., Storrick J., Columbus D., ORA user's guide, Carnegie-Mellon University, Pittsburgh 2018.

Cilliers P., What can we learn from a theory of complexity?, „Emergence” 2000, vol. 2, no. 1, s. 23-33.

Coleman J.S., Foundation of social theory, Harvard University Press, Cambridge 1990.

Creswell J.W., Poth C.N., Qualitative inquiry and research design: Choosing among five approaches, Sage, London 2017. 
Czakon W., Paradygmat sieciowy w naukach o zarządzaniu, „Przegląd Organizacji” 2011, nr 11, s. 3-6.

Engestrom Y., Activity theory as a framework for analyzing and redesigning work, „Ergonomics” 2000 , vol. 43, no. 7, s. 960-974.

Gell-Mann M., The quark and the jaguar: Adventures in the simple and the complex, Macmillan, New York 1995.

Guilford J.P., Fundamental statistics in psychology and education, McGraw-Hill College, New York 1977.

Hollenbeck J.R., Jamieson B.B., Human capital, social capital, and social network analysis: Implications for strategic human resource management, „Academy of Management Perspectives" 2015, vol. 29, no. 3, s. 370-385.

Holt G., Morris A., Activity theory and the analysis of organizations, „Human Organization” 1993, vol. 52, no. 1, s. 97-109.

Huang A., Knowledge sharing in a third-party-governed health and human services network, „Public Administration Review" 2014, vol. 74, no. 5, s. 587-598.

Krackhardt D., Simmelian tie: Super strong and sticky, [w:] R.M. Kramer, M.A. Neale (red.), Power and influence in organizations, Sage, Thousand Oaks 1998, s. 21-38.

Krackhardt D., The ties that torture: Simmelian tie analysis in organizations, „, Research in the Sociology of Organizations" 1999, vol. 16, no. 1, s. 183-210.

Krackhardt D., Kilduff M., Structure, culture and Simmelian ties in entrepreneurial firms, „Social Networks" 2002, vol. 24, no. 3, s. 279-290.

Larson C., Evidence of shared aspects of complexity science and quantum phenomena. Cosmos and History, „The Journal of Natural and Social Philosophy” 2016, vol. 12, no. 2, s. 160-171.

Merrill J., Keeling J.W., Carley K.M., A comparative study of 11 local health department organizational networks, „Journal of Public Health Management and Practice” 2010, vol. 16, no. 6, s. 564-576.

Morgan G., Images of organization, Sage, Thousand Oaks 1996.

Newman M., Networks: An introduction, Oxford University Press, Oxford 2010.

ORA-PRO, wersja 3.0.9.9.87, Carnegie Mellon University, School of Computer Science, Institute for Software Research, Pittsburgh 2018.

Papastefanou N., A complexity theory-based management framework for virtual organizations, „African Journal of Business Management” 2010, vol. 4, no. 11, s. 2323-2337.

Salancik G.R., Wanted: A good network theory of organization, „Administrative Science Quarterly" 1995, vol. 40, no. 2, s. 345-349.

Simmel G., The sociology of Georg Simmel, Free Press, New York 1950.

Stacey R.D., The science of complexity: An alternative perspective for strategic change processes, „Strategic Management Journal” 1995, vol. 16, no. 6, s. 477-495.

Ujwary-Gil A., Audyt zasobów niematerialnych z wykorzystaniem analizy sieci organizacyjnej, Wydawnictwo Naukowe PWN, Warszawa 2017.

Ujwary-Gil A., Network theory and complexity theory in the context of organization and management sciences, [w:] A. Ujwary-Gil, N.R. Potoczek (red.), Network, innovation and competence-based economy, Instytut Nauk Ekonomicznych Polskiej Akademii Nauk, Warszawa 2019, s. 79-97.

Ujwary-Gil A., Organizational network analysis: A study of a university library from a network efficiency perspective, „Library \& Information Science Research” 2019, vol. 41, no. 1, s. 48-57.

Wang Q., Gao S., Network architecture and firm performance: A resources-based view, „Frontiers of Business Research in China" 2011, vol. 5, no. 4, s. 559-579.

Wills-Johnson N., The networked firm: A framework for RBV, „The Journal of Management Development" 2008, vol. 27, no. 2, s. 214-224. 


\section{Streszczenie}

Celem rozdziału jest zidentyfikowanie osób (aktorów społecznych) najmniej zintegrowanych zadaniowo, najmniej powiązanych społecznie oraz o najniższej tak zwanej wspólnej świadomości sytuacji. Przesłanką badawczą jest spojrzenie na efektywność organizacji sektora informatycznego z perspektywy wielomodalnej metasieci składającej się z aktorów społecznych, wiedzy, zasobów i zadań. Metodykę badawczą stanowią badania sieciowe, w tym: określenie granicy sieci (organizacyjnej) oraz populacji badawczej; identyfikacja sieci relacji (definiowanie macierzy); mierniki analizy sieci organizacyjnej, takie jak: integracja zadaniowa (cognitive demand), więzi simmeliańskie (Simmelian tie) oraz wspólna świadomość sytuacji (shared situation awareness); korelowanie zmiennych za pomocą wykresów punktowych. Wyniki wskazały aktorów znajdujących się na obrzeżach sieci społecznej organizacji oferującej kompleksowe rozwiązania informatyczne dla biznesu w powiązaniu $\mathrm{z}$ doświadczeniem zawodowym poszczególnych aktorów, które wymagają pogłębionych analiz.

Słowa kluczowe: metasieć, aktorzy peryferyjni, integracja zadaniowa, więzi simmeliańskie, wspólna świadomość sytuacji, teoria sieci, teoria działalności, teoria zasobowa, teoria złożoności

\section{A meta-network approach to an IT organization from the perspective of the least socially integrated actors}

\section{Abstract}

The purpose of the article is to identify people (social actors) least task integrated, least socially connected and with the lowest shared situation awareness. The research premise is to look at the effectiveness of the organization from the perspective of a multimodal meta-network consisting of social actors, knowledge, resources, and tasks. The research methodology is network research, including defining the (organizational) network border and the research population; identification of relationship networks (matrix definitions); organizational network analysis metrics, such as cognitive demand, Simmelian tie, and shared situation awareness; correlating variables using scatter plot. The results indicated actors on the outskirts of the organization's social network in connection with the professional experience of individual actors, which require in-depth analysis.

Keywords: meta-network, peripheral actors, cognitive demand, Simmelian ties, shared situation awareness, network theory, activity theory, resource-based view, complexity theory 